\title{
МОТИВ БЕЗСМЕРТЯ У РОМАНІСТИЦІ ЛЕОНІДА ГОРЛАЧА
}

\author{
ОЛЬГА ФЕДЬКО \\ Запорізький державний медичний університет, Запоріжжя - Україна \\ fedko_olga@ukr.net; ORCID: 0000-0002-2993-9471

\section{MOTYW NIEŚMIERTELNOŚCI} \\ W POWIEŚCIACH LEONIDA HORŁACZA \\ OLHA FED'KO \\ Państwowy Uniwersytet Medyczny w Zaporożu, Zaporoże - Ukraina
}

STRESZCZENIE. Artykuł został poświęcony analizie funkcjonowania motywu nieśmiertelności w powieściach poetyckich Leonida Horłacza (Mamaj, Ruina, Czyste pole, Palec Askolda, Wyspa Stowiańska). Na podstawie prac P. Bargara, A. Wesełowskiego, I. Dziuby, J. Morgana, I. Sylantiewa, S. Thompsona przedstawiono osobliwości motywu jako formuły literackiej. Trafność badania wynika z mitologicznego korzenia inwariantnego motywu nieśmiertelności, jego wyjątkowej roli w kulturze ukraińskiej (i w ogóle światowej) i omijania tego tematu w studiach nad utworami L. Horłacza. Naświetlono wykorzystanie przez pisarza pogańskich i chrześcijańskich tradycji opisu życia po śmierci, potraktowanie nieśmiertelności jako cechy bóstwa albo nagrody i kary dla ludzi. Motyw nieśmiertelności jest również związany z pamięcią, sławą i wkładem osobistości we wspólne dzieło. Realizacji analizowanego motywu sprzyjają mitologemy, symbole i alegorie (nić Mojr, ogień, sad, pszczoła).

Słowa kluczowe: powieść poetycka, motyw, nieśmiertelność, symbol, mitologem

\section{THE MOTIF OF IMMORTALITY IN LEONID HORLACH'S NOVELS}

\author{
OLHA FEDKO
}

Zaporizhzhia State Medical University, Zaporizhzhia - Ukraine 
ABSTRACT. The article deals with the analysis of functioning of the immortality motif in L. Horlach's poetic novels (Mamay, Ruin, Open Field, Askold's Finger, Slavic Island). Based on the works of P. Bargar, A. Veselovskij, I. Dziuba, J. Morgan, I. Silantev and S. Thompson, the scecific nature of the motif as a literary element is presented. The relevance of the study is determined by the mythological origin of the invariant motif of immortality, its unique role in Ukrainian (and world-wide) culture and the lack of studies on this topic, all based on L. Horlach's works. This paper shows the writer's use of pagan and Christian traditions in describing the afterlife, the understanding of immortality as a feature of a deity or as a reward and punishment for people. The motif of immortality is also connected to the concept of memory, fame and the contribution of personalities to the common goal. The motif is analyzed using mythologies, symbols and allegories (the thread of Moirai, fire, garden, bee).

Keywords: verse novel, motif, immortality, symbol, mythologem

...Чи не обмежена поетична творчість відомими певними формулами, усталеними мотивами, котрі одне покоління прийняло від попереднього, [...] лише наповнюючи їх тим новим розумінням життя, котре власне і становить їі прогрес перед минулим?

О. Веселовський

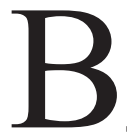

иклики, яке XXI століття ставить перед людством у всіх сферах діяльності, змушують переосмислити аксіологічні орієнтири та культурні домінанти. Саме „вміння маневрувати серед вже наявних у культуpi знаків, які треба і надалі вивчати, укорінює нас в культурні та історичні традиції, дозволяє нам осягнути власну ідентичність" [Januszkiewicz 2017: 137]. Однією з площин оприявнення прихованих смислів і надалі залишається художня література. Творчість Леоніда Горлача привертає увагу широтою охоплення національного буття українства в його темпоральній тяглості та багатством представлених культурософських мотивів. Попри наявність окремих досліджень різних аспектів віршованих романів митця, зокрема особливостей образотворення (В. Біляцька, Н. Мисливець, М. Неврлий), жанру (В. Біляцька, І. Закутна, Є. П'ятковська) та культурософії (С. Генова, І. Кропивко, О. Федько), романістика Л. Горлача потребує подальшого вивчення. Метою статті $є$ проаналізувати функціонування у творчості митця мотиву безсмертя як одного з провідних та найбільш фундаментальних у його культурософії.

Теоретичною базою дослідження є праці П. Баргара, О. Веселовського, Б. Гаспарова, I. Дзюби, О. Кирилюка, Дж. Моргана, І. Паперно, I. Силантьєва, А. Тимченко, Б. Томашевського, С. Томпсона, В. Халізєва, В. Шкловського, Л. Щемелєвої та ін. За визначенням І. Силантьєва, мотив -

це оповідний феномен, інваріантний за своєю приналежністю до мови оповідної традиції та варіантний у своїх подієвих реалізаціях, інтертекстуальний у своєму функціонуванні 
й такий, що отримує естетично значимі смисли у межах сюжетних контекстів, що співвідносить у своїй семантичній структурі предикативний первень фабульної дії з їі актантами й певними просторово-часовими ознаками [Силантьев 2004: 263].

Існування неподільної смислової одиниці в сюжеті помітили ще стародавні вчені. На архаїчній природі мотиву наголошує О. Веселовський, визначаючи його як „формулу, що відповідала на перших порах громадськості на питання, які природа всюди ставила людині, або яка закріплювала особливо яскраві, що здавалися важливими, або повторювані враження дійсності” [Beселовський 1989: 301]. Дослідження закорінених у міфологію мотивів, на думку П. Баргара, має широкий потенціал: такі мотиви допомагають „проєктувати нову, іншу реальність", простір імовірного, усвідомити невичерпність можливостей уяви, надають голос “непочутим”, загалом, „забезпечують вираження «іншому» у цій реальності на багатьох різних рівнях" [Bargar 2009: 87].

Привертаючи увагу дослідників своєю архаїчною природою, категорія мотиву отримує різні дефініції: синтагматичний елемент, пов'язаний із сюжетом і жанром [Шкловський 1929: 60], „тема нерозкладної частини твору” [Томашевський 1999: 121], смисловий елемент тексту (В. Халізєв, Л. Щемелєва, Б. Гаспаров, І. Паперно), „повторюваний та варіативний компонент літературних творів, який $є$ комплексом почуттів та ідей або концентрує уявлення про явище, дію" [Тимченко 2010: 7]. Узагальнивши думки дослідників, можна назвати такі основні риси цього поетикального складника: підвищена семіотичність, семантична цілісність, структурна й семантична неодномірність, елементарність (неподільність), повторюваність, образність, естетична значимість, предикативність (за наявності сюжетотвірної функції) тощо.

Архаїчна основа й повторюваність мотиву дозволяє говорити про його інваріантну природу. Так, С. Томпсон простежує функціонування мотивів як інваріантів і в розвитку дії, ситуацій, і в характеристиках персонажів. Сталість і відтворюваність мотиву протиставляється варіативності його реалізації у художньому тексті, яка відзначається більшою складністю порівняно з фольклорними творами. Отже, можна стверджувати про функціонування у художніх творах інваріантних мотивів, „кожний з яких, своєю чергою, реалізується множинністю конкретних фрагментів тексту” [Жолковский, Щеглов 1996: 261].

Мотив - структурно-семантична одиниця, „що здатна функціонувати на різних рівнях художнього тексту - ідейно-тематичному, сюжетному, оповідному, композиційному, просторово-часовому, персонажному і т.д.” [Гармаш 2014: 10-11], виконуючи предикативну, структуротвірну, імагогічну, стильову фунції. Дж. Морган вказує на те, що завдяки своїй інваріантній природі мотиви функціонують на трьох етапах роботи з твором: створення його наратором, акт читання і подальше переосмислення. Відтворювання мотивів у все нових і нових текстах культури розширює межі читацької співтворчості, адже „мотиви використовують, щоб розкрити думку, зобразити характер або 
увиразнити сцени, тому що читачі ...здатні розпізнати і оцінити такі алюзії” [Morgan 2015: 12].

Протягом тисячоліть людство намагалося пояснити феномен смертності і знайти шлях досягти безсмертя. Культурологи та соціологи (В. Горський, В. Звиглянич, О. Кирилюк, Р. Кісь, М. Парнюк та ін.) наголошують на діалектичній єдності категорій життя, смерть і безсмертя та їх фундаментальній ролі у світобудові будь-якого народу, що знаходить відображення у міфах, „історіях, які здатні апелювати до самої сутності людського існування” [Bargar 2009: 59]. У людській свідомості і зародження життя, і смерть - трансцендентні явища, волевиявлення вищої сили. Тому смерть уявлялася людям як перехід живої істоти з одного стану в інший, що підбиває підсумки життєвого шляху. Розуміння смерті як межового етапу зумовлює віру в те, що життя „черпає свої сили в смерті, безпосередньо з нею пов'язане і смертю очищується” [Маковский 1996: 154], тобто для людської душі смерть - це переживання катарсису, звільнення не лише від тілесної оболонки, але й від духовних страждань.

Міфологічний світогляд і гармонійне співіснування зі світом природи визначили сприйняття смерті як неминучого життєвого етапу: „життя породжує смерть, а смерть - життя. і те, й інше - лише різні боки єдиного коловороту буття. Вмерти - означає народжуватися знову” [Маковский 1996: 156]. Однак у спробі вивищитися над іншими біологічними видами людина запрагнула наблизитися до божественного і вибудувала концепцію безсмертя душі. „Ми хочемо думати про себе як про створених безсмертними і зі здатністю кидати виклик смерті, навіть у посмерті" [Maina 2009: 191], - зауважує О. Майна. Потрактування смерті як звільнення духу від фізичної оболонки яскраво простежується вже в античній традиції. У деяких релігіях створена божеством як вища істота людина втрачає безсмертя внаслідок покарання за злочин (зокрема, й у християнстві). Спроба “спокутувати гріх” і досягти безсмертя дала поштовх розквіту у Середньовіччі “мистецтва помирання” (ars moriendi) - визначеного церквою праведного шляху до Царства Небесного. У зв'язку з цим існування у світі живих розглядалося як тимчасовий етап випробувань і спокус, а істинно значущою уявлялася вічність після смерті. Науковий підхід до осмислення дійсності, вага емпіричного методу пізнання послаблюють віру у безсмертя людської душі і викликають відчуття страху перед невідомим. Попри це, філософи продовжують наголошувати на унікальності переживань, викликаних усвідомленням власної смертності і скороминущості життя. Помираючи, людина звільняється від умовностей і обмежень, нав'язаних соціумом, залишається сам на сам із собою, пізнає себе, свою ідентичність. “Думки про смерть” сповнюють жагою життя і допомагають віднайти внутрішню свободу.

Мотиви, що мають міфологічне коріння, й мотив іммортальності зокрема, „пов’ язують світ архаїки та сучасної людини” [Bargar 2009: 55] і пронизують 
тексти культури. Досліджуючи концепт безсмертя, В. Карасик слушно вказує на маркування його як чогось недосяжного та дихотомію „позитивної оцінки його реального відображення - довголіття, міцного здоров'я і ясного розуму у старості - та негативної оцінки безсмертя як вічного прокляття, кволої довгої старості та ланцюга перероджень, що призводять до безперервних страждань" [Карасик 2017: 151].

Мотив безсмертя є невід'ємним атрибутом культурософії романів Леоніда Горлача. Для персонажів його творів характерний міфологічний світогляд. і християни (Іван Мазепа, Іван Сірко, Ян Жижка, Ян Гус) і язичники (Аскольд і Дір до хрещення, Русана) вірять у потойбічне духовне існування, тому смерть для них - лише черговий етап життя. У романі Перст Аскольда особливу увагу привертає ритуальне самогубство Русани на похороні коханого: акт переходу до іншого світу показаний відповідно до язичницьких вірувань та супроводжується появою богині (,„пиходить Морена і веде за собою у землі свої” [Горлач 2008: 71]), причому потойбіччя характеризується позитивно за допомогою лексем „небеса”, „священні гаї”. Пошану та прийняття невідворотності смерті письменник підкреслює, називаючи божественну силу „ангелом смерті” та „милою бабусею” (звертання Русани). Персоніфікована смерть навіть запитує дівчину про добровільність ії рішення, що підкреслює роль Морани як провідника і вісника вищої сили, а не уособлення зла.

У козацькому суспільстві культивувалося „сприйняття смерті як неминучої, однак не фатальної, а усвідомленої”' [Якиминська 2006: 96]. Як захисники християнства козаки вірили в безсмертя людської душі і готові були скласти голову заради правого діла, прикладом чого є самопожертва Петра [Горлач 2008: 515]). Військові походи супроводжувалися загибеллю побратимів і постійним ризиком, тому смерть ставала явищем повсякденним і буденним. Л. Горлач, розкриваючи ставлення персонажів до смерті як частину світогляду описуваної доби, використовує і трансформує фольклорні елементи („Що смерть козаку? / Якщо ж і судилася доля погана, / вмирати судилося раз на віку!..” [Горлач 2008: 510], „Не п'єш - життя не маєш вічне / і п’єш - колись однак помреш" [Горлач 2010: 83]). Захисною реакцією виступала не лише віра у рай, але й життєствердний гумор: „Козак і на кутні зі смерті сміється” [Горлач 2008: 514].

Л. Горлач уповні залучає християнську міфологію для розгортання мотиву безсмертя. Продовжуючи традиції Енеїди І. Котляревського, митець зображує перебування душ у раю та пеклі. У викритті гріхів та злочинів значну роль відіграє національно-патріотичний аспект: „Тут смажаться твої сусіди - / і турки, й ляхи, й москалі / за те, що несли різні біди / Твоїй покраяній землі” [Горлач 2010: 100]. Історіософські погляди письменника оприявнюються при зображенні дріб'язкових чвар українців (,землячка рука надійна / тебе пригорне аж до дна" [Горлач 2010: 103]), адже саме внутрішній розбрат стає 
на заваді процвітанню української держави. Реалізація егоїстичних примх ціною нівеляції спільної ідеї - це фактично зрада національних інтересів, гідна “дев’ ятого кола” пекла. „І тут ми самоїди перші, / і тут нас підступи деруть. / Гриземось, яко раки в верші, / а нас тим часом інші б'ють” [Горлач 2010: 104], - формулює причину невдач і поразок українців легендарний Мамай.

Використання мотиву подорожі козака-характерника до пекла і раю перетворює читача на активного співглядача, який розділяє та оцінює побачене з головним героєм. Відверто суб'єктивна, ідеалізована візія козаків у раю („безневинно убієнні / в походах” [Горлач 2010: 113]), з одного боку, сприймається з певною іронією, але й водночас вибудовує прозору аксіологічну систему: пріоритетність інтересів свого народу, виправдання будь-яких здійснених на благо держави вчинків. Письменник наголошує на умовній цінності вічного буття; для діяльної козацької натури пастораль Царства Божого видається неповною („Ні, все тут є - тепло і спокій. / Але так хочеться мені / згубитись в ковилі високій / та погойдатись на коні" [Горлач 2010: 116]), адже вічне життя сповнюють сенсом активна діяльність і усвідомлення своєї мети. Саме тому в романі Перст Аскольда мотив іммортальності набуває форми покарання: за неправильне рішення щодо зміни релігії („Сам Русь розколов ти і ввергнув во гнів” [Горлач 2008: 157]) князь приречений на вічні сумніви і докори сумління. Аскольд прагне смерті як переходу душі на новий етап, однак залишається пасивним свідком страждань свого народу. Його кара посмертя, позбавлене спокою, гармонії й діяльності.

Для зображення людської долі письменник вдається до використання різних за походженням міфологем, символів та алегорій: відома з античних міфів нить Мойр („Твоє життя - тонка бринюча нить” [Горлач 2008: 605]), поширений в українському фольклорі та християнській традиції загалом чорний ворон як провісник смерті („Чорний ворон іще нам погибель не кряче” [Горлач 2010: 138]), бджола - уособлення людської душі, символ працьовитості, невтомності, творчої діяльності, духовної чистоти і безсмертя [Словник символів 1997: 12]. в українській культурі цей алегоричний образ використовують для підкреслення „самопожертви, вічного непокою заради інших” [Словник символів 1997: 13]. У романах Л. Горлача можна відзначити широке семантичне поле цього символу: спокій і гармонія, ідилічна картина [Горлач 2010: 77, 119, 120, 129; Горлач 2004: 73], плідна і тяжка праця [Горлач 2010: 16, 28 , 116, 128; Горлач 2008: 657], праведні, невинні душі [Горлач 2010: 24, 63, 142; Горлач 2004: 45, 66, 78; Горлач 2010: 651]. Образ цієї комахи в епілозі роману Чисте поле увиразнює праведність I. Сірка, сповнену спокою атмосферу пасіки [Горлач 2008: 662]. Цей епізод написаний у дусі християнських вірувань, адже політ бджоли символізує перенесення душі до раю [Словник символів 1997: 12]. Образ бджоли стає також незмінним атрибутом Царства Небесного як місця перебування праведних душ (,,рояться бджоли понад цвітом, / літають 
в сонячнім пилку, / зігріті щедро вічним літом / у вічнім райськім сповитку" [Горлач 2010: 113]).

Мотив іммортальності у романах Л. Горлача виходить за межі гарантованого релігією посмертя і набуває форми загальнолюдської пам'яті про конкретну особистість. І. Дзюба називає цей феномен „безсмертя в славі” і простежує його у давньогрецькій культурі як „свого роду доповнення до античного... безсмертя душі” [Дзюба 2014: 656]. Демонстрація людиною найвищого рівня руйнівної або творчої сили була шляхом до вічної слави. Л. Горлач усі подвиги героїв наповнює глибоким духовним змістом, тому воїни-полководці Жижка і Корибут прирівнюються у посмерті до мученика Яна Гуса (Слов'янський острів). Їхні військові дії мали на меті добробут людей, а не свій власний (на відміну від егоїстичних вчинків спраглого слави героя міфів - Ахілеса), тому є не просто частиною історії, а й культурним феноменом народу. На символічному рівні письменник показує внесок цих діячів у спільну справу за допомогою символу вогню: „Твоє палахтіння собою, як зможу, продовжу, / щоб тільки світання скоріше до чехів прийшло" [Горлач 2008: 473]. Цікавим у цьому контексті видається потрактування А. Протоповою та І. Протоповим прометеївського вогню, що виходить за рамки фізичного дару людям і постає, подібно до філософської концепції стоїків, „носієм власне первня розуму, з якого виникають душі людей у їхніх тілах" [Протопопова, Протопопов 2019: 53].

Особлива роль образів наставників, народних ватажків у творах Л. Горлача дозволяє говорити про використання в них архетипу Мудрого Старого [Федько 2018]. Закономірно, що письменник не оминає й проблеми покликання та суспільної місії митця. Глибока національна укоріненість культурософії аналізованих романів проявляється і в алюзії на ідею сродної праці, в усвідомленні персонажем-поетом власного призначення: „Усе життя шукав себе у світі / і тут знайшов, де вишні у цвіту, / Де вічне все, як вічний ти при тому, / Бо і тебе вродило недарма" [Горлач 2010: 64]. Розвиваючи ідею безсмертя духовних провідників нації, Л. Горлач вдається до порівняння „поетів від Бога" з Мамаєм, який є уособленням народного духу.

Саме як акт творіння безсмертного образу Мамая можна розглядати і написання віршованого роману про легендарного характерника, і водночас увіковічення самого письменника через його працю. К. Дмітрієв слушно вказує на те, що „у літературному дискурсі загальновизнано нерозривний зв'язок між силою уславити та силою зробити безсмертним і іманентну присутність цієї сили у поезіï” [Dmitriev 2017: 107]. Користуючись таким потенціалом художнього твору, письменник міфологізує постать Мамая в однойменному романі практично до рівня божественного. Безсмертя у всіх філософіях і релігіях - це передусім атрибут вищої сили: „Що ти, Боже! Ти ж вічний, Ти наша опора, / Ти творець наш, Ти радісний промінь живла" [Горлач 2010: 21]. Відтворюючи 
розмови характерника з Богом, наділяючи козака іммортальністю, магічною силою, роллю покровителя і хранителя народу, Л. Горлач творить свій міф про безсмертний дух народу („вічний Мамаю” [Горлач 2010: 18], „Ти правічний Мамай, в тебе віку без ліку” [Горлач 2010: 23], „Мамай же непідвладний смерті" [Горлач 2010: 97]). Наскрізна думка роману про значення народної вітальності та акумулятора пам’яті розкривається вже в епіграфі: „Ти подумай: народ наш тому лише вічний / що Мамай оживля його знову і знов” [Горлач 2010: 8]. Письменник утверджує у цьому образі домінанти запорозького характеру: нестримну вдачу, гумор та карнавальний спосіб життя. Принцип зображення подібний до описів вад і пристрастей мешканців Олімпу, а не канонізованих християнських святих. Услід за поширеною у міфах традицією розглядати людську віру як джерело сили божества автор також зображує Мамая залежним від пастви: „допоки я живу в народі, / я доти вічний, я - Мамай” [Горлач 2010: 117]. Саме іммортальна природа образу Мамая наповнює його існування вищим смислом і виступає гарантом досягнення ним мети.

Отже, у віршованих романах Леоніда Горлача уповні реалізовано потенціал інваріантного мотиву безсмертя. Автор поєднує язичницькі й християнські традиції, потрактовуючи вічність як атрибут божества або винагороду чи покарання для смертних. Мотив іммортальності втілено як у традиційних для християнства формах (опис пекла і раю в романі Мамай), так і в тісному зв'язку з поняттями слави та пам'яті, роллю особистості в розвитку національної культури (Мамай, Слов'янський острів). Для розкриття цього мотиву письменник залучає міфологеми та символи різного походження (нить Мойр, вогонь, сад, бджола тощо).

\section{Список використаної літератури}

Веселовский А., Историческая поэтика, Москва: Высшая школа, 1989.

Гармаш Л., Теория мотива в литературоведении, [в:] „Наукові записки Харківського національного педагогічного університету ім. Г.С. Сковороди. Серія: Літературознавство”, 2014, вип. 1 (2), с. 10-22.

Дзюба I., Слава, [в:] Дзюба I., „Історія української літератури у дванадцяти томах”, т. 4: „Тарас Шевченко”, Київ: Наукова думка, 2014, с. 655-675.

Жолковский А., Щеглов Ю., Работы по поэтике выразительности: Инварианты - Тема Приемы - Текст, Москва: Прогресс, 1996.

Карасик В., Сюжетный мотив „, бессмертие”: нарративное измерение концепта, [в:] „Сибирский филологический журнал”, 2017, № 4, с. 149-162.

Маковский М., Сравнительный словарь мифологической символики в индоевропейских языках: Образ мира и миры образов, Москва: ВЛАДОС, 1996.

Протопопова А., Протопопов И., Сюжет о сотворении людей в мифе о Прометее у Фульгенциия, [в:] „Studia Litterarum”, 2019, т. 4, № 4, с. 44-57. 
Силантьев И., Поэтика мотива (Язык. Семиотика. Культура), Москва: Языки славянской культуры, 2004.

Словник символів, ред. О. Потапенка, К. Дмитренка, Київ: Редакція часопису „Народознавство", 1997.

Тимченко А., Мотивна структура поезї Володимира Свідзінського, автореф. ... канд. філол. наук, Харків, 2010.

Томашевский Б., Теория литературы. Поэтика, Москва: Аспект Пресс, 1999.

Федько О., Культурософські мотиви у романістииі Леоніда Горлача: особливості функціонування, дисертація ... канд. філол. наук, Запоріжжя, 2018.

Шкловский В., О теории прозы, Москва: Федерация, 1929.

Якиминська Л., Особливості менталітету украӥнського козацтвва, [в:] „Інтелігенція і влада", 2006, вип. 8, с. 93-97.

Bargar P., Mythical Motifs in Literary Works: M. Bulgakov's „,Master and Margarita” and G. Orwell's , 1984”, [in:] „Communio Viatorum”, 2009, LI (1), p. 55-88.

Dmitriev K., Glory and immortality: the motif of monumentum aere perennius by Samaw'al b. 'Ádiyā', [in:] „Religious Culture in Late Antique Arabia”, 2017, p. 105-121.

Januszkiewicz M., Znak i interpretacja. Czy możliwa jest semiotyka hermeneutyczna?, [w:] „Przestrzenie Teorii”, 2017, nr 28, s. 129-138.

Maina O.M., Exploring the motifs of death and immortality , [n:] „Journal of Language Technology \& Entrepreneurship in Africa”, 2009, vol. 1,issue 2, p. 187-197.

Morgan J., How do motifs endure and perform? Motif theory for the study of biblical narratives, [in:] „Revue Biblique”, 2015, vol. 122, no 2, p. 194-216.

Thompson S., Motif-Index of Folk-Literature: A Classification of Narrative Elements in Folktales, Ballads, Myths, Fables, Medieval Romances, Exempla, Fabliaux, Jest-Books, and Local Legends, Bloomington: Indiana University Press, 1955-1958, vol. I-VI.

\section{Spysok vykorystanoi literatury [References]}

Veselovskij A., Istoricheskaja pojetika [Historical poetics], Moskva: Vysshaja shkola, 1989.

Garmash L., Teorija motiva v literaturovedenii [The theory of motif in literary criticism], [v:] „Naukovi zapysky Kharkivskoho natsionalnoho pedahohichnoho universytetu im. H.S. Skovorody. Seriia: Literaturoznavstvo", 2014, vyp. 1(2), s. 10-22.

Dziuba I., Slava [Glory], [v:] Дзюба I., „Istoriia ukrainskoi literatury u dvanadtsiaty tomakh”, t. 4: „Taras Shevchenko”, Kyiv: Naukova dumka, 2014, s. 655-675.

Zholkovskij A., Shheglov Ju., Raboty po pojetike vyrazitelnosti: Invarianty - Tema - Priemy Tekst [Studies in a poetics of expressiveness: Invariants - Theme - Device - Text], Moskva: Progress, 1996.

Karasik V., Sjuzhetnyj motiv ,, bessmertie”: narrativnoe izmerenie koncepta [The subject matter motif ,Immortality”: a narrative dimension of the concept], [v:] ,Sibirskij filologicheskij zhurnal", 2017, nr 4, s. 149-162. 
Makovskij M., Sravnitelnyj slovar mifologicheskoj simvoliki v indoevropejskih jazykah: Obraz mira i miry obrazov [Comparative dictionary of mythological symbols in Indo-European languages: The image of the world and the worlds of images], Moskva: VLADOS, 1996.

Protopopova A., Protopopov I., Sjuzhet o sotvorenii ljudej v mife o Prometee u Fulgencija [Creation myth and the Prometheus myth in Fulgentius], [v:] „Studia Litterarum”, 2019, t. 4, nr 4, s. 44-57.

Silantev I. , Pojetika motiva (Jazyk. Semiotika. Kultura) [Poetics of Motive (Language. Semiotics. Culture)], Moskva: Jazyki slavjanskoj kultury, 2004.

Slovnyk symvoliv [Dictionary of symbols], red. O. Potapenka, K. Dmytrenka, Kyiv: Redaktsiia chasopysu „Narodoznavstvo”, 1997.

Tymchenko A., Motyvna struktura poezii Volodymyra Svidzinskoho [The motif structure of Volodymyr Svidzinskyj’s poems], avtoref. ... kand. filol. nauk, Kharkiv, 2010.

Tomashevskij B., Teorija literatury. Pojetika [Theory of Literature. Poetics], Moskva: Aspekt Press, 1999.

Fedko O., Kulturosofski motyvy u romanistytsi Leonida Horlacha: osoblyvosti funktsionuvannia [The cultorosophical motifs in Leonid Horlach's novels: the specificity of functioning], dysertatsiia ... kand. filol. nauk, Zaporizhzhia, 2018.

Shklovskij V., O teorii prozy [Theory of Prose], Moskva: Federacija, 1929.

Yakymynska L., Osoblyvosti mentalitetu ukrainskoho kozatstva [Features of the mentality of the Ukrainian Cossacks], [v:] „Intelihentsiia i vlada”, 2006, vyp. 8, s. 93-97.

Bargar P., Mythical Motifs in Literary Works: M. Bulgakov's „,Master and Margarita” and G. Orwell's ,, 1984”, [v:] „Communio Viatorum”, 2009, LI (1), p. 55-88.

Dmitriev K., Glory and immortality: the motif of monumentum aere perennius by Samaw'al b. 'Ádiyā', [v:] „Religious Culture in Late Antique Arabia”, 2017, p.105-121.

Januszkiewicz M., Znak i interpretacja. Czy możliwa jest semiotyka hermeneutyczna? [Sign and interpretation. Is hermeneutical semiotics possible?], [v:] „Przestrzenie Teorii”, 2017, 28, s. 129-138.

Maina O.M., Exploring the motifs of death and immortality, [v:] „Journal of Language Technology \& Entrepreneurship in Africa”, 2009, vol. 1, iss. 2, p. 187-197.

Morgan J., How do motifs endure and perform? Motif theory for the study of biblical narratives, [v:] , Revue Biblique, 2015, vol. 122, nr 2, p. 194-216.

Thompson S., Motif-Index of Folk-Literature: A Classification of Narrative Elements in Folktales, Ballads, Myths, Fables, Medieval Romances, Exempla, Fabliaux, Jest-Books, and Local Legends, Bloomington: Indiana University Press, 1955-1958, vol. I-VI.

\section{Список використаних джерел}

Горлач Л., Мамай. Мазепа, Київ: Ярославів Вал, 2010.

Горлач Л., Руїна, Київ: Бібліотека українця, 2004.

Горлач Л., Слов'янський острів, Київ: Дніпро, 2008. 


\section{Spysok vykorystanykh dzherel [References]}

Horlach L., Mamai. Mazepa [Mamay. Mazepa], Kyiv: Yaroslaviv Val, 2010.

Horlach L., Ruina [Ruin], Kyiv: Biblioteka ukraintsia, 2004.

Horlach L., Slovianskyi ostriv [Slavic Island], Kyiv: Dnipro, 2008. 
